This is the accepted version of a forthcoming article that will be published by Wiley in Antipode: http://onlinelibrary.wiley.com/journal/10.1111/(ISSN)1467-8330

Accepted version downloaded from SOAS Research Online: http://eprints.soas.ac.uk/22394/

\title{
Absent Regions: Spaces of Financialisation in the Arab World
}

By Adam Hanieh, SOAS University of London

\section{Introduction}

From its early roots in Marxian political economy, the term 'financialisation' has emerged over recent years as a popular conceptual framework through which to describe and analyse the increased weight of financial markets within contemporary capitalism. While finance has always been a core feature of how capitalism operates - and, indeed, is intimately connected to the emergence of the world market itself - the last three decades has witnessed a pronounced shift in the degree to which accumulation pivots around financial processes. An oft-cited definition by Epstein (2006: 3) sees financialisation in the expansion of financial motives, markets, actors and institutions both domestically and internationally. Finance has "penetrated across all commercial relations to an unprecedented direct extent" (Fine 2010: 13), such that all capitalist social relations including those between capitals, as well as those between capital and labour - are now mediated by interest-bearing capital (McNally 2009: 56). Underlying this shift has been a proliferation of new financial instruments and markets, notably based upon the securitisation of assets and derivative contracts, which have greatly augmented the volume of global financial flows, as well as increased the underlying crisis tendencies of the system as a whole. Importantly, this shift does not simply have economic implications, but has also permeated every sphere of social and cultural life (Christopherson et.al. 2013).

There remains vigorous debate over the general concept of financialisation and related issues such as why finance has become ascendant, its relationship to neoliberalism and US hegemony (Dumenil and Levy 2005; Crotty 2005; Panitch and Gindin 2012), and whether it should be considered a new phase of capitalism itself (Boyer 2000; BellamyFoster 2007; Lapavitsas 2013). Some scholars, most notably Christophers (2013; 2015), have warned that the "accumulated weight of the myriad meanings" attached to financialisation (Chrisophers 2015: 186) gives the notion itself only limited utility. An important aspect to all these discussions is empirical: what indicators are best used to demonstrate that processes of financialisation are actually taking place? In this respect, numerous contributions over the past decade have suggested different ways of measuring the size, influence and activity of the financial sector. Theoretically, these empirical trends have been connected to changes in the ways that accumulation occurs within capitalism, as well as the impact of financial markets on the behavior of institutions, individuals and states.

This political economy literature provides a rich and varied set of insights into understanding and assessing changes to contemporary financial markets. For the purposes of this paper, however, two major limitations of this work should be highlighted. The first of these is that the vast majority of academic work on 
financialisation has concentrated on the core capitalist countries - particularly the US, UK and Japan (and to a lesser degree, France and Germany). As is widely acknowledged within the literature itself, there has been relatively little written on what financialisation looks like outside the advanced core. ${ }^{1}$ The work that has been done in this regard has been restricted to a handful of countries, notably, Brazil, South Korea and Turkey - and has largely focused on how these countries are inserted into global financial flows, rather than mapping the specificities of their own domestic financial markets. ${ }^{2}$

In a related sense, the second weakness to the political economy literature is a relative neglect of the spatial/scalar dimensions of financialisation - a gap that has been particularly recognised by scholars of geography. Four years ago, French et al, made a challenging call to 'financialise space and space financialisation', arguing that there was "a glaring lacuna at the heart of the financialisation project; that is, its relatively uncritical approach to the role of space and place within monetary and financial processes" (2011: 805). The profound spatial shifts associated with financialisation represented both an "analytical opportunity and political economic imperative" for integrating geography into the wider finance literature (Pike and Pollard 2010: 29). Particularly in the wake of the mutations of the global financial crisis, there was a foremost need for "for a more geographically sensitive reading of the myriad of processes associated with financialization ... and the new financial spaces and practices to which it is giving rise" (Hall and Leyshon 2013: 832). Encouraged by calls such as these, much of the subsequent work within geography has reassessed the political economy literature through a critical but sympathetic gaze.

With these two limitations in mind, I want to ask what we can learn about financial transformations through examining their dynamics in the Arab countries of the Middle East and North Africa, or what will be termed henceforth the 'Arab world'. Arab countries have been almost completely absent from the debates on financialisation "falling off the map" as Bassens et al have similarly noted in regard to World Systems theory and Islamic financial services (2010: 37). But as I show below, many of the features commonly associated with financialisation are also evident in this region. This is not simply a problem of incompleteness, or the need to stack up an endless series of case studies. Rather, if we are to take seriously the notion that capitalism is a global system and that the 'whole' is more than simply the additive sum of its parts - then, without a full understanding of the variegated ways in which financialisation works outside of the core, we lack a real appreciation of the actual phenomenon itself (even within the core).

As part of this investigation of financialisation in the Arab world, I aim to show its deeply spatial inflexion, and thus the importance of incorporating space and scale into our understanding of the concept more generally. In this respect, Christophers (2015: 192) has recently argued that we need to be wary of "geographically anaemic" approaches to financialisation, which treat national economies as spatially bounded and methodologically divorced from international flows of capital. Financialisation is much more than simply the expansion (or deepening) of financial markets and institutions

\footnotetext{
${ }^{1}$ Exceptions are the work of scholars associated with the Research on Money and Finance (RMF) and the International Initiative for the Promotion of Political Economy (IIPPE), which I draw upon below.

2 See Bonizzi (2014) for literature review.

${ }^{3}$ This paper focuses on three main geographical areas: (1) The hydrocarbon-rich monarchies of the Gulf Cooperation Council (GCC) - Saudi Arabia, Kuwait, Bahrain, Qatar, United Arab Emirates and Oman; (2) North African countries of Morocco, Tunisia, Algeria, Libya and Egypt; and (3) Mashreq countries of Syria, Iraq, Lebanon, Jordan and the Palestinian Authority.
} 
within neatly circumscribed sets of social relations operating at the national scale. Specifically, in the Arab world, financialisation has been marked by the growing weight of regionally-active finance capital - most specifically, those capital groups based in the six states of the Gulf Cooperation Council (Saudi Arabia, Kuwait, United Arab Emirates, Qatar, Bahrain and Oman) - in circuits of capital operating at all scales. Approaching financialisation in this manner - moving away from methodologically nationalist assumptions and the literature's largely singular focus on the advanced capitalist core thus brings into focus the significance of cross-scalar accumulation patterns, their spatial hierarchies, and geographic unevenness.

In developing this argument, the article is organised in three main parts. In the following section, I explore the academic literature on financialisation, its measurement, and various theorisations of how institutions, markets and individuals subsequently behave. The literature on these points is extensive, and by no means do I claim to provide a comprehensive survey. Rather, the aim is to distil some key observations that can be examined in the context of the Arab world, and to reaffirm the case made by geographers for the importance of financialisation's spatiality. The two sections that follow concretely map financialisation in the Arab world, drawing in part upon an original study of the balance sheets, annual reports and shareholder information of around 300 banks and non-financial firms in the Arab world (using both Arabic and English sources). Section 3 assesses the degree to which financialisation can be said to exist in the region, and its impact on key sectors and institutions. It develops a range of indicators that demonstrate these trends - including the relative growth in financial assets, the changing behaviour of non-financial firms, and the composition of bank lending and bank income. Section 4 extends this analysis beyond the lens of the national scale, demonstrating that financialisation must be understood alongside the re-scaling of accumulation and a shifting balance of class power in the region. This has important implications for how we approach the concept of financialisation and its relationship to processes of class formation.

\section{Financialisation}

The seemingly unstoppable growth of financial markets and new financial instruments has generated scholarly debates across a range of interconnected issues. These issues include, most fundamentally, the place and nature of finance within wider capitalist accumulation - is finance 'productive' or a form of fictitious capital (Christophers 2013)? Is it a new phase of capitalism (Lapavitsas 2013, Boyer 2000), or does it signal capitalist stagnation in an environment of over-accumulated surplus (Bellamy-Foster 2010) or declining profit rates (Brenner 2006; Harman 2009)? How does the rise of finance link to the seemingly endless mutations of crisis and the nature of contemporary class relations - both between labour and capital, as well as different fractions of capital itself (Albo et al 2010)? In debating all of these themes, scholars have necessarily grappled with what constitutes 'finance' - and, therefore, the 'non-financial' - as well as a complex set of questions concerning the relationship between finance, the money form, and the various sub-divisions of surplus value.

For the purposes of the argument that follows, there are four key claims of this literature that need emphasis. The first of these is that financialisation is a process that brings fundamental changes to how accumulation takes place across all firms - not simply the financial sector (Krippner 2005: 182). This financialisation of the non-financial is a trend acknowledged in both mainstream economic literature (Gorton 2015: 279), as well as by 
more critical scholars. On the one hand, it signifies a change in how profits are generated - with business calculus shifting towards the maximisation of stock price and 'shareholder value', rather than simply the sale of commodities (Crotty 2005: 88; also see Froud et al 2000). With non-financial firms connected more tightly to financial markets, financial assets become much more central to balance sheets and income generation. It also means a change in the way that non-financial firms typically fund themselves coming to rely more on the issuance of equity and debt securities rather than traditional bank borrowing (Lapavitsas 2013: 219-222). All of these dynamics impact internal firm organization and management goals, as well as the wider tendency to crisis in capitalist economies.

A second important feature of financialisation is the transformation in how individuals and households reproduce themselves on both a day-to-day and long-term basis (Albo et al 2010; Fine 2010; Lapavitsas 2013). Closely associated with the erosion of social provisioning of housing, education, health and aged care under neoliberalism, households have become increasingly dependent upon financial markets to ensure basic needs. This is reflected in the substantial growth of mortgage and housing finance, the increasingly direct linkage of pensions to the fortunes of capital markets, and the rise of various forms of market-based insurance as a means of managing risk. Lapavitsas notes that this process constitutes a "financialization of personal revenue ... through which the financial sector [mediates] the private provision of goods and services to households" (Lapavitsas 2013: 240). Another indicator, therefore, of the degree of financialisation within any economy, is the growth in lending for mortgages and personal consumption purposes (and their relative weight in overall loan volumes).

Connected to these changes in both non-financial firm and household behaviour is a third major characteristic of financialisation - a transformation in the operations of banks. Here, commercial banks have moved away from a focus on corporate lending towards a direct role in mediating financial markets. They have become the nexus between financial markets and other capitalist firms, assisting the latter through the issuing of bonds, equities and derivatives. Dos Santos has shown empirically that that this transformation is reflected in the rising importance of 'non-interest income' to bank profits (Dos Santos 2009). Through their mediating role with financial markets, banks make money through fees, commissions, and their own proprietary fund management rather than lending directly to corporations. At the same time, as individuals have been pushed onto a dependence on the market, banks play another mediating role around "access to housing, durable consumer-goods, education, and increasingly health-care, though insurance-, mortgage- and other individual loans" (Dos Santos 2009: 182). Revenues from the lending to individuals and households thus become increasingly central to bank profitability.

The question of how banking has changed within contemporary capitalism relates closely to the fourth important theme of this literature: the impact of financialisation on the structure and forms of the capitalist class itself. In a survey of earlier literature, Krippner points out that banks are frequently the most highly interlocked of all firms in the economy - cross-directorships across different firms most often involve bank directors (Krippner 2005: 201). This should not be read as implying the domination of industrial capital by banking capital, but rather as the emergence of a much more tightly interlocked capitalist class straddling both financial and non-financial firms. Indeed, the financialisation hypothesis is particularly suggestive on this point - pointing to the need to move beyond a simple antimony between 'industry' and 'finance' to instead consider 
the convergence of control that cuts across sectoral boundaries - what has been classically described by Hilferding, Lenin and others as 'finance capital'. The leading position of this "new social type" (Krippner 2005: 201) signifies the presence of the same individuals "on the boards of the largest banks and [non-financial] corporations presiding over ... investments, organizing production, sales, and financing, and appropriating the profits of their integrated activities" (Zeitlin, quoted in Krippner 2005: 201). Financialisation, in other words, is intimately connected to the changing dynamics of class formation - a point to which I shall return below.

These four themes of the financialisation literature inform much of the analysis that follows in Sections 3 and 4. As noted above, however, one of the weaknesses of the financialisation literature is its lack of critical attention to the spatiality of finance. The implications of this have recently been drawn out by Christophers (2013; 2015), who argues that we need to be very careful not to assume that financialisation can be understood (and measured) as a process occurring within bounded sets of social relations, neatly enclosed in distinct and separable national spaces that then impact on one another in a purely external fashion. This methodologically-nationalist bias leads much of the literature to view finance as inherently 'national', territorialised within discrete national containers that are posited as the natural vantage point from which to analyse the operation of markets and institutions (Christophers 2013: 239-241). Embedded in this dominant approach (although, almost always implicit), is the ontological assumption of a binary opposition between the interior and exterior of these national containers - the 'foreign' and 'domestic'.

Taking on board Christophers' critique, I fully agree that an understanding of financialisation needs to reject the notion that "explanations of 'national' economic outcomes" can be found "exclusively in "national' economic dynamics" (Christophers 2013: 243). Instead, we need much more sensitivity to the question of geographic scale (Smith 1993; Swyngedouw 1997; Brenner 2001) - incorporating the global, regional, national, sub-national, local and so forth, as different sites through which financial flows are territorialized, regulated and contested (Sokol 2013). Following Neil Brenner, this 'scale question' should not be understood simply in the sense of pre-given boundaries, or different levels, which separate distinct geographic units from one another (2001: 599). Rather, scales are always internally-related, to employ the incisive concept of the Marxist philosopher Bertell Ollman - they do not exist as discrete 'things' but only as part of a larger whole (Ollman 2003). The relations between scales are essential to how scales themselves are actually constituted, and thus analytical focus must be placed on mapping the ways in which these intra-scalar relations are constantly in flux. The spatiality of capitalism, in other words, is characterised by a continual process of rescaling - a "perpetual reworking of the geographies of capital circulation and accumulation" (Swyngedouw 1997: 68) - that shifts the ways in which different scales are internallyrelated and hierarchised.

An appreciation of scale not only holds implications for how financialisation itself is interpreted and measured - but also for how social relations are conceived of, and change, within and across scales. Precisely because rescaling processes take place through "capital circulation and accumulation", they necessarily involve the imbrication of different sets of social relations - and thus classes - across scales; confounding any conception of class as a set of self-enclosed social relations circumscribed, or contained, a priori within the national scale. This critical point directs our attention to the ways in which financialisation necessarily intersects with processes of class formation - a 
relationship which, in my opinion, has remained somewhat under-explored in the geography literature despite the latter's often-explicit linkages to Marxian frameworks and geographers.

Drawing together these analytical threads, what I aim to demonstrate below is that financialisation in the Arab world has been intrinsically associated with a rescaling of accumulation. It is a process that both works through, and acts to reproduce and reinforce, the tying together of financial markets across multiple spatial scales. My analysis emphasises the regional scale for reasons that will hopefully become evident. Importantly, however, this does not mean that one particular scale is the privileged site of accumulation; rather, accumulation at all scales has become more tightly entwined with regional finance capital. Not only does this reveal the distinctive 'spaces of financialisation' in the Arab world, it carries important insights into the character of class formation in the area.

Before turning to this empirical investigation there is one feature of Arab finance that should be noted: the presence of Islamic finance (IF) and shariah-compliant products, which forbid the earning of interest and disallow investments believed to contradict Islamic principles. While IF constitutes a fairly small proportion of financial systems in most Arab countries, particularly those outside the Gulf, the region is viewed as a core zone of Islamic finance at a global level. ${ }^{4}$ For the thematic purposes of this article, however, IF should not be seen as fundamentally incongruous with the conceptualisation of financialisation described above. As with standard Marxian approaches to the circuit of capital, Islamic financial instruments seek an increase in an original sum of loanable money capital advanced over time (M...M'). Due to the interdiction on interest-bearing products IF technically differs from conventional finance in how this increase occurs; but in practice, IF instruments closely resemble their non-Islamic counterparts. ${ }^{5}$ This does not mean that IF is unimportant to how Arab financial markets operate - notably in relation to the region's relationship with financial markets in East Asia, or the forms of internationalisation of Gulf finance capital (see below) - but a full exploration of these issues lies beyond the scope of this article. ${ }^{6}$

\section{Assessing Financialisation in the Arab World}

The recent trajectory of the political economy of the Arab world holds many similarities to other areas of the world. Driven by the 1980s debt crisis and the tightening grip of authoritarian regimes, most non-GCC Arab states embarked on liberalisation measures under the aegis of international financial institutions and their structural adjustment plans. These changes were hesitant at first - and met with substantial social protest - but

\footnotetext{
${ }^{4}$ According to the Islamic Financial Services Board, four Arab countries have 'systematically important' IF sectors (where Islamic assets constitute more than $15 \%$ of total banking assets): Saudi Arabia (51.3\%), Kuwait (38\%), Qatar (25.1\%) and the UAE (17.4\%) (IFSB 2015: 9).

${ }^{5}$ In the case of Islamic mortgages the bank buys the property on behalf of the individual client. The client then buys it back by paying higher instalments (murabahab) or through monthly payments that involve a repayment of the purchase price and a 'rent' until the property is fully owned (ijara). For Islamic bonds (sukuk), the bond-holder technically does not lend money, rather, they own a share of whatever the money was used to purchase, and earn income from profits generated by that asset or rental payments made by the sukuk's issuer. At the end of the term, the issuer buys back the share of the asset owned by the lender (equivalent to paying the principal). Even forms of forward contracts exist within Islamic finance (salam and istisna'), despite the Islamic principle that commodities should not be exchanged prior to their coming into existence.

${ }^{6}$ See Bassens et al 2010 for further discussion.
} 
by the 1990s neoliberal perspectives had gained a hegemonic position within the policy arrangements of governments across the region (Hanieh 2013). Of course there was large variability in both the pace and scope of neoliberal reform - Egypt, Tunisia, Jordan and Morocco stand out as those states where change was deepest - but no Arab country was immune to this shift. By 2008, the World Bank was acclaiming the Middle East as the second fastest region for economic reform in the world; Egypt - long held up as a regional role model by international financial institutions - was anointed as the world's 'best reformer' in the same year.

The financial system has been a key strategic lever through which these policies have unfolded. From the 1950s to the 1980s, banking and the financial markets of most Arab countries had been state dominated - capital markets were anaemic or non-existent, interest rate levels and the supply of credit generally controlled by the state, and foreign financial institutions largely excluded from Arab markets. ${ }^{7}$ Through the initial decades of the $21^{\text {st }}$ century, however, this picture changed appreciably. By early 2015, the average market share of state-owned banks in non-GCC Arab countries sat at 38 percent of total assets, down from 56\% in 2001. ${ }^{8}$ Burgeoning capital markets emerged across the region in which foreign investors were active. ${ }^{9}$ Indicating the core function of the financial sector within wider neoliberal reform processes, this expansion of stock markets has been closely linked to deepening privatisation trends as the sell-off of state-owned assets occurred through stock market IPOs. Moreover, a number of mutual funds, insurance companies and other non-banking financial intermediaries were launched across the region. At the level of monetary policy, government ceilings on interest rates were lifted and market-based provision of credit expanded considerably. Again these aggregate trends hide significant variation, most notably in Algeria, Syria and Libya where financial systems remained largely under state control through the early 2000 s - but even in these three countries the effects of 'financial deepening' were felt.

Given these trends, what do the standard measures of financialisation indicate for the region? Table 1 shows four typical indicators for the magnitude of the financial sector and its relative importance across 14 Arab countries.

\section{$<$ Table $1>$}

The data in Table 1 indicates that through the 2008-2014 period, all 11 Arab countries for which information was available had banking sector assets exceeding $70 \%$ of GDP (compared to only 7 countries in the 2000-2007 period). Moreover, in 7 out of 11 of these countries the ratio was well in excess of $100 \%$ (compared to only 4 reaching this level in the earlier period). Notably, these latter years coincided with the global financial crisis and the regional turmoil that followed the 2011 Arab uprisings - a period in which financial assets could have been expected to decline. With the exception of Kuwait and Syria, financial system deposits to GDP have also increased very significantly across all

\footnotetext{
${ }^{7}$ Egypt nationalised its 27 banks following the 1952 revolution - merging these into four state-owned banks that would direct credit to target sectors. In Morocco, Tunisia and Algeria, interest rates were set by the state, and all banks were compelled to lend to state institutions. Only in Lebanon was the banking system largely market-based, and for this reason the country formed an entrepot to the wider global economy.

${ }^{8}$ Calculations for 2015 using Bankscope Database; 2001 figure from Farazi et al (2011).

${ }^{9}$ The major exception is Saudi Arabia's Tadawul market, the largest stock exchange in the region. Until recently, foreign investors were only able to invest in Tadawul through a limited number of mutual funds. In early 2015, however, the Saudi government announced that the market would be gradually opened to foreign investment.
} 
listed countries. Table 1 also points to the relative weight of financial companies on Arab stock markets. The proportion of market capitalisation represented by the finance sector ranges from just over 35\% in Saudi Arabia, where oil-related companies predominate, to $75.7 \%$ in Bahrain. In six out of ten countries, more than half of all stock market capitalisation is constituted by these companies. Even more strikingly, seven out of ten countries have more than $60 \%$ of total stock market profits earned by financial companies. For Bahrain, Jordan, the UAE and Tunisia, close to three-quarters of all profits in listed companies are connected to finance. In some countries this ratio has increased extremely rapidly - in Egypt, for example, finance-related profits constituted $11.2 \%$ of profits in $2005,27.9 \%$ of profits in 2009 , and have now reached $69.4 \%$ of total listed profits. For Jordan, the financial sector's share of total market profits jumped by nearly 25 percentage points between 2009 and $2015 .^{10}$

Accordingly, it appears from these standard indicators that there has been a definite growth in the magnitude and weight of the financial sector across the Arab world. As discussed above, however, an important feature of financialisation - perhaps more significant than simply the relative size of the financial sector - is the way in which it changes accumulation patterns for all firms, including the non-financial sector. What happens when we turn to examining this 'financialisation of the non-financial'? Unfortunately, the kind of data that researchers have used to measure this trend in other contexts is not directly available in any consistent or longitudinally satisfactory manner for the Arab world. I have thus developed an alternative indicator (Figure 1) that attempts to measure the degree to which 'non-financial' firms are enmeshed with financial markets. This data draws upon the publically available consolidated balance sheets for 22 of the largest non-financial companies across the GCC, Egypt and Jordan (three key financial markets in the region). Taken together, these companies make up around one-half of both the total market capitalisation, and total assets, for the top 100 non-financial companies across these countries. They include the largest Arab firms operating in the chemical and minerals, food, telecommunications, utilities, ports, logistics, aircraft, and cement sectors. Using their audited annual balance sheets from 2003 to 2014 (in Arabic, where English is unavailable) I have determined the proportion of company assets that are dependent upon, or linked to, financial markets. These include: equities available for sale, short-term investments held for trading, derivatives, and investments in associate companies. These figures have been weighted according to the company's market capitalisation (in US\$) for the specified year, and then the two-year moving average of the total calculated. The aim of this exercise is to develop a proxy indicator for non-financial companies' income - and thus accumulation - that depends upon financial markets/instruments rather than simply revenue arising from the production and sale of commodities.

\section{$<$ Figure 1 $>$}

Figure 1 strongly suggests the growing centrality of financial markets to Arab nonfinancial companies. The proportion of financial assets to total assets grew from around $4.5 \%$ in $2003 / 2004$ to $19.5 \%$ in $2013 / 2014$ - a remarkable and very sharp jump for just ten years. It should be emphasised that these companies are market leaders in their respective sectors, and a study of smaller or medium-size companies may not show identical trends; but the figures appear to confirm that financial markets play a much more important role in the business strategies of the region's most significant non-

\footnotetext{
${ }^{10}$ Calculated from stock exchange data.
} 
financial firms. This shift has been particularly notable over the latest five-year period, but interestingly there was surprisingly little decrease in this ratio during the financial crisis of 2008-2009 - despite the fact that all Arab markets experienced double-digit declines at this time. This resilience to crisis is perhaps an indication that financialisation represents more than simply an efflorescent market phenomenon, but actually marks a qualitative shift in how accumulation takes place in the region.

\section{Changing role of banks?}

The final set of indicators for financialisation concern the transformation in the operation of financial institutions - particularly banks - over the last quarter of a century. Table 2 shows the proportion of non-interest income to total income for commercial banks across 14 Arab countries. This ratio has fluctuated much more sharply than the other data discussed above: moving rapidly upwards from 1998 to 2007 and then dropping again in the period following the 2008-2009 global economic crisis and the recent Arab uprisings. Nonetheless, despite these fluctuations, the overall proportion has generally trended upwards, with non-interest income reaching close to $35 \%$ of banking income across all countries during the 2010-2013 period, up from just over $27 \%$ in 1998 2001. Only Egyptian banks witnessed a significant decline between these two periods. ${ }^{11}$ It is also noteworthy that during the 'boom' years of 2004-2007, the GCC countries experienced a very sharp jump in this ratio, particularly in three of the largest banking markets of the region - Saudi Arabia, the UAE and Qatar.

\section{$<$ Table $2>$}

The rise in non-interest income likely points to the growing role of Arab banks as mediating links between financial markets and corporations (see Dos Santos above). In this sense, a greater proportion of non-interest income - achieved through fees, commissions and bank's own trading of financial instruments - is an expected corollary to the financialised turn of Arab capital in general. At the same time, household borrowing has become much more central to the loan profiles of banks. Lending for personal consumption now makes up around $40 \%$ of total bank credit to the private sector in Bahrain, Oman, Kuwait, Egypt and Tunisia - for the latter two countries, this figure has approximately doubled over the last decade. ${ }^{12}$ Personal consumption loans also constitute a significant proportion of bank assets in Qatar (29\%), the UAE (32\%), Saudi Arabia (26\%) and Jordan (26\%). Placed alongside the recent expansion of household mortgage markets across key Arab states ${ }^{13}$, these figures confirm that individuals and households are increasingly reliant upon financial markets to meet their day-to-day needs, and, as a consequence, the lending profiles of Arab banks have been transformed.

The data analysed in this section must be treated with some caution - statistics for the region frequently lack depth and there are significant gaps in coverage. Cross-country comparisons are not always possible due to different underlying variables. It is also important not to overstate these trends. For many of the standard indicators typically

\footnotetext{
${ }^{11}$ In Egypt, the proportion of non-interest income fell by around 20 percentage points in both 2008-2009 and 2010-2011.

${ }^{12}$ Figures mid-2015, except for Tunisia, end-2014 (calculated from Central Bank annual reports).

${ }^{13}$ One standard measure of housing finance is mortgage loans as a \% of (current) GDP. From 2010-2015, this figure has increased from $16 \%$ to $18.1 \%$ in Jordan, $11.8 \%$ to $19 \%$ in Lebanon, $10.7 \%$ to $16 \%$ in Morocco, and $13.3 \%$ to $18 \%$ in Tunisia. For Tunisia, it has recently been estimated that $40 \%$ of the active population's income is spent on mortgage debt (UN-Habitat 2011: 63).
} 
used to measure 'financial deepening' by international financial institutions - the penetration of non-bank financial institutions (pension and mutual funds, insurance companies and so forth), the depth of corporate debt markets, and the ability to trade futures and derivatives ${ }^{14}$ - the Arab world lags behind other regions. Nonetheless, we should not think of financialisation as a closed process with a definitive end-point, but rather as an ongoing feature of contemporary capitalism. In this respect the conclusions are clear: the principal characteristics of the Arab financial system - from the magnitude of the financial sector, to the behavior of non-financial firms, and the changing role of banks and bank-lending - all confirm that the trends of financialisation noted in the general literature are applicable to the region itself.

\section{Rescaling Financialisation}

What happens, however, if we unsettle the methodological nationalism that characterises many of the assumptions behind the indicators above, and consider financialisation through the lens of other scales? In order to answer this question, I aim to demonstrate that financialisation in the Arab world has occurred alongside a rescaling of accumulation, in which accumulation processes at all scales are increasingly entangled with, and shaped by, those at the regional scale. Principally, this rescaling has been driven by the internationalisation of Gulf-based finance capital throughout the Arab world. Financialisation, therefore, is as much a reflection of this scalar process linked to the internationalisation of capital, as it is simply a quantitative growth or change in the ways that financial markets intermediate the behavior of firms and individuals at the national level.

But before spelling out this argument in greater depth, it is necessary to more precisely delineate what I mean by GCC 'finance capital' - a term that has hitherto been used fairly loosely. In many ways, the case of the GCC substantiates how classical Marxist theorists - including Hilferding, Lenin and others - framed the notion of finance capital (see Marois 2012 for overview). While these conceptions differ in emphasis, finance capital is broadly understood as the merging of both financial and industrial capital within large conglomerates that are closely connected to the state apparatus. This amalgamation denotes the emergence of a class that cuts across (and controls) both financial and non-financial activities. Banks and other financial institutions play very important roles as a pivotal nexus of this process, although - as noted above - this should not be read as simply the domination of banks over industry as it is sometimes interpreted.

Similarly, within GCC capitalism, accumulation is dominated by large business conglomerates that are typically structured around holding companies straddling all moments of the circuit of capital (Hanieh 2011). Subsidiaries and a dense network of interlocking directorships mean that these conglomerates control a wide variety of industrial, trading and financial activities. These conglomerates generally originate from influential merchant groups or ruling families. In many cases, their emergence was linked to a role as contractors to foreign oil companies, the import trade, or construction activities associated with the early urbanisation of the Gulf states in the first quarter of the $20^{\text {th }}$ century.

\footnotetext{
${ }^{14}$ Aside from Kuwait, future and options trading have not been possible in Arab stock markets. The NASDAQ Dubai exchange launched a derivatives market in 2008 but as a result of the global crisis it did not succeed and the last contract traded there in 2011.
} 
For the purposes of this article there are two features of GCC finance capital that require particular emphasis. ${ }^{15}$ First, it is important not to place an artificial division between the 'state' (and thus the ruling families) and the capitalist class itself (Hanieh 2015). The ruling families of the Gulf certainly dominate the political apparatus of the state, but they also need to be seen as part of the capitalist class - indeed, they often form the central core of this class. Concretely, this means that movement between the 'public' and 'private' spheres is extremely fluid, and that individuals from the ruling family will frequently own private businesses alongside holding positions in the state apparatus. There is thus a tight interlocking between 'state' and 'private' capital; privately-owned companies will often have public officials (including members of the ruling family) on their boards, and, equally, the boards of state-owned companies will include prominent business people. In a closely related sense, government funds invest alongside (and in) these private conglomerates or associated companies - in this manner, state revenues from the sale of hydrocarbons are redirected into the accumulation circuits of GCC finance capital.

The second important feature of GCC finance capital is the centrality of banks and other financial institutions to the underlying configuration of the large business conglomerates. All of the leading banks in the GCC have representatives of these business conglomerates sitting on their boards and as investors (alongside state capital). Gulf banks are by far the largest in the Arab world (see below), and, unlike other Arab countries, the ownership of these banks remains generally in national hands. In this manner, GCC banks act as a critical nodal point for different fractions of Gulf finance capital and the state, acting to pool and redistribute funds through a variety of markets and economic activities. This is not meant to imply that banks 'dominate' industry or vice-versa; rather, these financial institutions form a pivotal site through which Gulf finance capital comes to envelop all moments of accumulation.

An excellent illustration of these patterns is shown by the National Bank of Kuwait (NBK), which was established by a group of Kuwaiti businessmen in 1952 as the first locally-owned Gulf bank. Today, NBK is the sixth largest bank in the Arab world (by assets) and the largest in Kuwait, controlling more than one-fifth of all banking assets in the country. NBK is listed on Kuwait's stock exchange (indeed, it was the first shareholding company established in the GCC), and is controlled by the most important segments of Kuwaiti finance capital. Its board of directors, for example, has representatives from the $\mathrm{Al} \mathrm{Kharafi} \mathrm{Group} \mathrm{-} \mathrm{one} \mathrm{of} \mathrm{the} \mathrm{original} \mathrm{founders} \mathrm{of} \mathrm{the} \mathrm{bank} \mathrm{-}$ best known for the massive Kuwaiti Food Company (Americana) that owns a vast network of restaurants and food manufacturing plants across the Middle East. Confirming the ways in which GCC finance capital straddles all economic sectors, Kharafi also controls some of the region's largest industrial and commercial companies, including firms involved in construction, cement production, civil engineering, real estate development, tourism, and information technology. Alongside $\mathrm{Al}$ Kharafi, other principal owners of NBK include the Al-Bahar, Al-Sager, and Al-Fulaij Groups - each of these conglomerates similarly span a range of business sectors. Finally, NBK is closely connected to the Kuwaiti state itself - with the government-run Public Institution for Social Security holding a major stake in the company.

\footnotetext{
${ }^{15}$ An additional feature of GCC capitalism not discussed here but that should nonetheless be noted is the region's overwhelming reliance on a non-citizen workforce. This class structure underpins the unique configuration of state-citizen relations, and has facilitated the spatial displacement of crises at key moments (e.g. the 2008-2009 global downturn). See Hanieh $(2011$; 2015) for further elaboration.
} 


\section{Internationalisation of GCC finance capital}

Across the entire GCC, finance capital has been characterized by these patterns of accumulation and institutional forms for many decades. But since the beginning of the $21^{\text {st }}$ century, there has been a major shift in the spatial organisation of these capital groups, with Gulf finance capital (both state and private) expanding rapidly throughout the Arab world. ${ }^{16}$ Through this process of internationalisation, the GCC has come to dominate cross-border capital flows in the region. From 2003 to 2015, for example, the GCC was responsible for a remarkable $42.5 \%$ of total greenfield FDI in non-GCC Arab states. ${ }^{17}$ More than half of all foreign investments in Jordan, Egypt, Libya, Lebanon, Palestine and Tunisia came from the Gulf over this time. Mergers and acquisitions (M\&A) figures provide further evidence of these trends. From 2010 to 2015, European, Gulf, and North American investors spent just over 20 billion euros on M\&A in the Arab World the GCC share of this was $44.7 \%{ }^{18}$ Moreover, these figures significantly understate the level of internationalisation over this period - they do not include, for example, the considerable government-to-government flows of aid from the Gulf that have been apparent in recent years, and do not necessarily incorporate portfolio investments by Gulf firms in regional stock markets.

The particular phasing of these flows is not simply the result of greater quantities of petrodollars associated with higher oil prices; rather this internationalisation of Gulf capital has been directly connected to the deepening neoliberal turn of Arab governments. In addition to the financial sector measures noted earlier, neoliberal policies brought the privatisation of state-owned industries, the liberalisation of foreign ownership laws, and measures aimed at attracting foreign investment flows (Hanieh 2013: 47-98) - Gulf finance capital was a prime beneficiary of this policy turn. In this manner, neoliberalism and the internationalisation of Gulf capital need to be thought of as co-constitutive and mutually-reinforcing processes; their inherently cross-scalar nature confounds any methodologically nationalist readings of the Arab world's political economy.

This changing spatiality of Gulf finance capital returns us to the question of financialisation and the regional scale. Financial institutions and financial markets, as many scholars have noted, are key enablers of internationalisation itself. It is thus not surprising that - as part of its internationalisation - GCC finance capital has become deeply involved in the regional financial circuit. Table 3 illustrates this process through examining Merger and Acquisitions (M\&A) data for banks, insurance and financial services in nine Arab countries outside of the GCC. The data captures the relative weight of GCC, European and North American capital flows ${ }^{19}$ into the Arab financial sector from 2006 to 2015 ( $1^{\text {st }}$ quarter).

\section{$<$ Table $3>$}

\footnotetext{
${ }^{16}$ This does not mean that Gulf investments went primarily to the region (US and Europe remained the principal focus). Relatively, however, the Gulf's weight within regional accumulation circuits grew in comparison to historical patterns and other foreign investment sources.

${ }^{17}$ Figures from country information reports, Arab Investment \& Export Credit Guarantee Corporation http://www.iaigc.net/ (in Arabic). Jordan, Egypt, Lebanon, Tunisia, Libya, Iraq, Morocco, Syria, Palestine and Algeria.

${ }^{18}$ Investment from EU (28), North America and the GCC, going to Algeria, Egypt, Jordan, Lebanon, Morocco, Palestine, Syria and Tunisia. Calculated from Zephyr M\&A database. Figures include only confirmed M\&A deals with known values.

${ }^{19}$ Virtually all FDI flows into the region originate from one of these three blocs.
} 
The results both confirm the dramatic internationalisation of Gulf finance capital over the last decade, as well as the Gulf's weight in the regional finance circuit. In all countries, with the exception of Morocco, the overwhelming proportion of capital flows into finance has come from the Gulf. Taken in total across the nine countries, $65 \%$ of the 14.3 billion euros of foreign investment in the financial sector over this period originated from the Gulf, with most of the remainder (31\%) coming from EU-28 countries. North American investment has been negligible. If Morocco is excluded from these figures, the Gulf's proportion reaches a staggering $72.7 \%$ of total investment originating from the three areas. Arab financial liberalisation, in other words, has been primarily and overwhelmingly characterised by the internationalisation of Gulf finance capital.

Table 4 provides further corroboration of this process and its profound implications for banking at the national scale. The data is drawn from an examination of shareholder structures and boards of directors for 280 banks across the eleven listed countries. It shows the degree to which GCC-related banks ${ }^{20}$ control (i) a country's total banking assets, and (ii) total non-state owned banking assets. The results reveal that banks closely connected to GCC finance capital completely dominate the non-state owned banking systems in Jordan, Syria, Palestine, Egypt and Lebanon. In each of these states, GCCrelated banks hold more than $50 \%$ of all non-state owned bank assets - reaching a remarkable $86 \%$ in the case of Jordan. In Yemen, Algeria, Tunisia, Iraq, and Libya, GCCrelated banks also hold a significant share of non-state banking assets - ranging from $19.3 \%$ to $45 \%$. In four of these latter countries (Yemen, Tunisia, Iraq and Libya), GCC investors hold more of the banking sector than any other foreign country (for Algeria, French-related banks hold 52\% of non-state banking assets). Moreover, Table 4 shows that in those countries where high levels of state-ownership persist (Algeria, Libya, Iraq and Syria), the GCC's proportion of overall bank assets is considerably less than that within the non-state banking sector alone. In those states where the private ownership of banks is most advanced - such as Jordan and Lebanon - GCC-related banks have overwhelming predominance. Bank privatisation, in other words, is intertwined with, and reinforced by, the internationalisation of GCC finance capital.

\section{$<$ Table $4>$}

The one outlier to the overall trends observed in Table 4 is Morocco, where French and Spanish banking groups dominate foreign ownership. There are several indications, however, that this is changing. In 2014, the Arab world's largest bank (by assets), Qatar National Bank, launched its African strategy that targets Morocco as its base for the North African market. QNB has plans to purchase the largest bank in Morocco, Attijarawafa Bank, which would completely transform the ownership structures of Morocco's banking sector. Moreover, Morocco illustrates how Islamic finance appears to be emerging as an important vehicle for the regional expansion of GCC finance capital. Islamic banks have hitherto been outlawed in the country due to the elite's traditional hostility to Islamism, but, in January 2015, new laws were passed that allowed the establishment of IF institutions. According to industry analysts, the passage of these laws was an explicit "attempt to attract Gulf money" (Golcer 2014: 4). Confirming this

\footnotetext{
20 This term refers to any domestic bank that fulfills one or more of the following characteristics: (1) GCC shareholders hold $20 \%$ or more of the bank's shares, (2) a minimum of two GCC investors sit on the board of directors, (3) the bank is a subsidiary of another GCC financial institution. In this sense, the term reflects the degree of cross-border, intra-regional enmeshing of class relations within banking.
} 
assessment, the Qatar International Islamic Bank (QIIB) announced in late December 2015 that it was launching a joint venture with a major Moroccan bank, CIH Bank, to establish the first new Islamic Finance bank in Morocco (in which QIIB would hold 40\% of assets).

The GCC-related banks analyzed in Table 4 are often the largest and most important financial institutions in their respective countries - a fact confirmed by their weight in regional stock markets. Out of all the banks listed on stock markets across Lebanon, Jordan, Egypt, Tunisia, Palestine, Syria and Iraq, six of the largest seven (by market capitalisation) are GCC-related. ${ }^{21}$ Strikingly, GCC-related banks constitute $57 \%$ of the entire market capitalisation of all banks listed on these seven markets. The ten largest GCC-related banks alone control just under $40 \%$ of all listed banking assets in these seven countries - five of these ten banks are direct subsidiaries of GCC banks. Moreover, the weight of GCC finance capital in Arab markets appears to be deepening despite the regional crises of recent years. ${ }^{22}$

One consequence of these trends is the accentuating uneven development of the regional scale as a whole - a divergence between the weight of GCC finance capital and the rest of the region. This growing unevenness is shown by aggregate figures for bank profits and bank assets. In 2000, for example, banks located in the GCC held $62 \%$ of all banking assets in the Arab world. ${ }^{23}$ By 2014 , this figure had reached $71.7 \%$. The pre-tax profits of GCC banks constituted 70\% of all Arab bank profits in 2012-2014, up from an average of $57 \%$ in 2007-2008. Even those characteristics of bank income directly associated with financialisation indicate this polarisation - in 2014, more than $70 \%$ of all non-interest income earned across the entire Arab banking system flowed to GCC-based banks. Most pointedly, these 'national' figures do not take into account the ways in which GCC-based capital has expanded through the forms of internationalisation indicated in Tables 3 and 4 - at a purely quantitative level, they thus considerably understate the actual position of the GCC within Arab financial markets.

It is important to underline, however, that the Gulf's centrality to Arab financialisation should not be viewed simply as a predatory, hostile take-over of other Arab capitalist classes. Rather, the cross-scalar knitting together of accumulation under the hegemony of Gulf finance capital is better seen as signifying a regional entwinement of class structures, with considerable benefits often extending to non-GCC Arab capitalists. Gulf capital's involvement in many of the banks analysed in Table 4, for example, has enabled leading Egyptian, Jordanian and other Arab capital groups to embark on their own processes of expansion and internationalisation. ${ }^{24}$ In other cases, large non-GCC Arab conglomerates rely primarily upon Gulf markets despite being formally based outside of the GCC. This

\footnotetext{
${ }^{21}$ Calculated from stockmarket data.

${ }^{22}$ In Egypt, for example, GCC-based banks have dramatically increased their weight since 2013 - this includes the UAE-based Emirates-NBD acquisition of BNP-Paribas (Egypt), the sale of National Societe General Bank to Qatar National Bank, and the purchase of Greek-owned Piraeus Bank by Kuwait's Al Ahli Bank.

${ }^{23}$ Calculated from Bankscope database. Countries included are Algeria, Bahrain, Egypt, Iraq, Jordan, Kuwait, Lebanon, Morocco, Oman, Palestinian Territory, Qatar, Saudi Arabia, Syrian Arab Republic, Tunisia, United Arab Emirates, Yemen.

${ }^{24}$ One example is the Bank of Palestine, founded in 1960 by the Gaza-based Al Shawa family. In 2008, the Kuwaiti conglomerate MA Kharafi \& Sons became BoP's largest shareholder, taking 9\% of the bank's capital, with the Al Shawa family retaining a significant holding. Following this investment, BoP significantly expanded, increasing its number of branches by more than $50 \%$ in five years, and becoming the leading Palestinian bank in the West Bank and Gaza Strip.
} 
is a particularly notable characteristic of capitalist classes in Palestine, Jordan and Lebanon - and in some prominent examples the relationship with the GCC is recognized by joint citizenship. ${ }^{25} \mathrm{~A}$ more recent indication of the cross-regional interlocking of accumulation is a trend of Arab capital groups utilising GCC stock markets as their principal location for IPOs and raising credit. ${ }^{26}$ These examples - to which many more could be added - reveal how GCC financial circuits are not external to the national scale, but rather, should be seen as internally related to processes of class formation and accumulation across all Arab countries.

\section{Conclusion}

Taken together, these profoundly spatial dimensions of financialisation in the Arab world indicate both the consolidation of the power of GCC finance capital at the level of the regional scale, and, simultaneously, the interiorisation of this class within other Arab states. Viewed from the perspective of the regional scale, the key features of financialisation outlined in Section 3 - the growing size and weight of financial assets and financial profits, the increasing importance of financial income for non-financial firms, the changing nature of bank lending, and so forth - can all be understood as reflecting, enabling, and girding this projection of regional power by Gulf-based finance capital. Financialisation in the Arab world thus not only signifies the assertion of financial markets within individual states, but a rescaling of accumulation itself; the imbrication of all scales within regionally articulated circuits dominated by Gulf finance capital.

This has important implications for understanding many contemporary features of the region. For one, the presence of both deepening financialisation and GCC-dominated pan-regional linkages is found in numerous key industries: construction, agribusiness, logistics, transport, telecommunications, Islamic finance, retail, renewable energy, and so forth. The future trajectories of these strategic sectors will be largely shaped by their entwinement with Gulf financial circuits. This regional interlocking also undermines any conception of a binary opposition between foreign and domestic capital, in which the latter is invested with some kind of progressive political potential (the ras al-mal al-watani - 'patriotic bourgeoisie' - heralded by some Arab Left and nationalist movements). Instead, the dynamics discussed here point to how the Arab 'national' bourgeoisie has become largely inseparable from accumulation in the Gulf. This is perhaps one reason why the GCC has come to embody and defend the interests of other Arab business and state elites in such a prominent manner - as the various regional alliances established in the wake of the 2011-2012 revolts confirm.

More generally, approaching financialisation from this perspective reveals why analyses of financial processes need to move beyond a view of the national scale as a self-enclosed and 'natural' spatial container of social relations. When we measure, for example, the rapid growth in consumer and real estate lending in Jordan, we are also seeing the manner in which GCC finance capital increasingly intermediates Jordanian social relations. When we observe the growing proportion of financial profits on the Egyptian stock market, we are simultaneously mapping how Egyptian capitalism has become

\footnotetext{
${ }^{25}$ Lebanon's Hariri family (who also hold Saudi citizenship) is an archetypal example, but many others exist.

${ }^{26}$ A good example was the 2015 announcement that the Egyptian conglomerate Orascom Construction would move its primary share listing to Dubai and keep a secondary listing in Cairo. Orascom is controlled by the most important business family in Egypt, the Sawaris, and the decision to shift its listing to the Gulf is highly indicative of the orientation of Arab capital to Gulf financial markets.
} 
closely enmeshed with circuits of accumulation in the GCC. Financialisation, to employ one of Marx's favourite concepts, constitutes a 'form of appearance' of this shifting spatialisation of accumulation; a renascent reworking of space and scale, such that the dynamics of accumulation and class formation emerge anew. Beyond the direct implications for scholars concerned with the political economy of the Middle East, these examples hold potentially useful insights for other geographical locations. Their specificities will clearly differ from place to place, but the Arab world provides a compelling argument for more careful attention to these emerging spaces of financialisation.

\section{Bibliography}

Albo, Greg, Sam Gindin and Leo Panitch (2010). In and Out of Crisis: The Global Financial Meltdown and Left Alternatives. PM Press.

Bassens, David, Ben Derudder and Frank Witlox (2010). "Searching for the Mecca of finance: Islamic financial services and the world city network". Area; 42: 35.

Bellamy-Foster, John (2010). 'The Financialization of Accumulation', Monthly Review 62:5.

Benner, C., Berndt, C., Coe, N., Engelen, E., (2011) Emerging themes in economic geography: outcomes of the economic geography 2010 work- shop, Economic Geography, 87: 111-126.

Bonizzi, Bruno (2014). "Financialization in Developing and Emerging Countries A Survey" International Journal of Political economy, vol. 42, no. 4, Winter 2013-14, pp. 83-107 for a useful literature review.

Boyer, R. 2000. "Is a Finance-Led Growth Regime a Viable Alternative to Ford- ism? A Preliminary Analysis." economy and Society 29, no. 1: 111-45.

Brenner, N (2001) "The limits to scale? Methodological reflections on scalar structuration" Progress in Human Geography 25,4 (2001) pp. 591-614.

Brenner, R. (2006). The Economics of Global Turbulence: The Advanced Capitalist Economies from Long Boom to Long Downturn, 1945-2005, London: Verso Books.

Christophers, Brett (2013) Banking Across Boundaries Placing Finance in Capitalism, (Maldan, MA: Wiley-Blackwell).

Christophers, Brett (2015). "Limits to Financialization", Dialogues in Human Geography, Vol. 5(2) 183-200.

Christopherson, S., Martin, R. \& Pollard, J. (2013), 'Financialisation: Roots and repercussions', Cambridge Journal of Regions, Economy and Society, 6(3): 351-57.

Crotty (2005) The Neoliberal Paradox: The Impact of Destructive Product Market Competition and Impatient Finance on Nonfinancial Corporations in the Neoliberal Era in Epstein, G. (ed) Financialization and the World Economy. Northampton, MA: Edward Elgar. 
Dos Santos, Paulo L. (2009). "On the Content of Banking in Contemporary Capitalism", Historical Materialism, 180-213.

Dumenil, G. and Levy, D. (2005) 'Costs and Benefits ofNeoliberalism: A Class Analysis', in G. Epstein (ed.), Financialization and the World Economy, Cheltenham: Edward Elgar.

Epstein, Gerald (ed.), (2005). Financialization and the World Economy. Cheltenham: Edward Elgar.

Farazi, Subika Erik Feyen, and Roberto Rocha (2011) "Bank Ownership and Performance in the Middle East and North Africa Region", World Bank Policy Research Paper 5620, (Washington DC: World Bank).

Fine, Ben. (2010). "Neoliberalism as Financialisation" in Economic Transitions to Neoliberalism in Middle-income Countries, Alfredo Saad-Filho and Galip Yalman (Eds) (Routledge: New York).

French, S., A. Leyshon and T. Wainwright (2011) Financializing space, spacing financialization. Progress in Human Geography 35.6, 798-819.

Froud, J., C. Haslam, S. Johal, K. William. 2000. "Shareholder value and financialization: consultancy promises, management moves," Economy and Society, Vol. 29 (1): 80-110.

Golcer "Islamic Finance Bulletin”, Gulf One Lancaster Centre For Economic Research, June 2014.

Gorton, Gary (2015). The Maze of Banking: History, Theory, Crisis, Oxford University Press.

Hall, Sarah and Andrew Leyshon, (2013). "Editorial: Financialization, Space and Place", Regional Studies, Vol. 47, No. 6, 831-833.

Hanieh, Adam. (2011). Capitalism and Class in the Gulf Arab States, Palgrave-Macmillan: New York.

Hanieh, Adam (2013). Lineages of Revolt: Issues of Contemporary Capitalism in the Middle East. Chicago: Haymarket Books.

Hanieh, Adam (2015) 'Capital, Labor, and State: Rethinking the Political Economy of Oil in the Gulf.' in Amal Ghazal and Jens Hanssen (Eds.) The Oxford Handbook of Contemporary Middle-Eastern and North African History, available online at http://www.oxfordhandbooks.com/view/10.1093/oxfordhb/9780199672530.001.0001 /oxfordhb-9780199672530-e-3

Harman, Chris. 2009. Zombie Capitalism: Gobal crisis and the relevance of Marx (London: Bookmarks)

Islamic Financial Services Board (ISFB), (2015) Islamic Financial Services Industry: Stabliyt Report 2015, (IFSB: Kuala Lumpur Malaysia). 
Krippner, Greta, (2005). 'The Financialization of the American Economy', Socio-Economic Review 3, pp. 173-208.

Lapavitsas, Costas (2013). Profiting without producing: how finance exploits us (London: Verso).

Marois, Thomas (2012) "Finance, Finance Capital, and Financialisation." Fine, Ben and Saad Filho, Alfredo, (eds.), The Elgar Companion to Marxist Economics. Cheltenham: Edward Elgar.

Panitch, Leo and Sam Gindin (2012) The Making of Global Capitalism, London: Verso.

Pike, A. and J. Pollard (2010) Economic geographies of financialization. Economic Geography 86.1, 29-51.

Ollman, Bertell (2003). Dance of the Dialectic: Steps in Marx's Method (Urbana, IL: University of Illinois Press, 2003).

Smith, N. (1993) "Homeless/global: scaling places," in J. Bird, B. Curtis, T. Putnam, and T. Tickner, eds, Mapping the Futures, London: Routledge, 87-119.

Sokol, Martin (2013). "Towards a 'newer' economic geography? Injecting finance and financialisation into economic geographies", Cambridge Journal of Regions, Economy and Society 2013, 6, 501-515.

Swyngedouw, E. A. (1997) 'Neither Global nor Local: 'Glocalization' and the Politics of Scale," in Cox, K., ed Spaces of Globalization: Reasserting the Power of the Local. New York: The Guilford Press. pp. 137-66.

United Nations Human Settlements Programme (UN-HABITAT), (2011) Tunisia Housing Profile, (Nairobi: UN-Habitat). 
